日植病報 $34: 137 \sim 139$ (1968)

Ann. Phytopath. Soc. Japan $34: 137 \sim 139$ (1968)

\title{
イネ白葉枯病病原細菌の寄主体侵入に関する 解剖学的観察，とくに萎凋症状株の組織解剖
}

\author{
田部 井英 夫*
}

Hideo TABEI*: Anatomical Studies of Rice Plant Affected with Bacterial Leaf Blight, with Special Reference to Wilt Symptom

\begin{abstract}
The wilting of rice seedlings appeared at high rate when inoculated at the four leaf stage in the nursery by immersed in bacterial suspension $\left(10^{5}\right.$ cells $/ \mathrm{ml}$ ) for 16 hours. Most of the lower leaves of wilted seedlings showed ordinary yellow blight symptom and the sixth leaves wilted, whereas the fifth leaves did not show any symptoms.

Histological study revealed that the primary infection occurred only at the hydathode of the lower leaves which were already developed at the time of inoculation, and that the wilting of the upper leaves was due to the vessel embolisms caused by the secondary colonization of those infecting bacteria. The reason why the fifth leaf was not wilted, was that the vessels of this leaf are connected with those of the third leaf where bacterial multiplication was insufficient to induce the wilting. In general, the vessels of the even-numbered leaves did not connect with those of the uneven-numbered leaves. So far as this study, no direct invasion of the bacteria through the roots and the basal parts of the stems was found.

In several cases, the rupture of the infected vessels and bacterial exudation to the intercellar spaces of the parenchyma were observed. The vessels were always ruptured from the inside of the vessels and the infection of the healthy vessels by those exudated bacteria was never recognized.
\end{abstract}

(Received September 23, 1967)

イネ白葉枯病による異常生育, 特に急性菱调症につ いて, 吉村 $\left.{ }^{9}, 10\right)$ は病原細菌が苗の茥基部から感染し, 約 4 週間の潜伏增殖期を経てその部分の維管束の閉そ くと組織崩壊がおここる結果, 萎调症状が発現すると推 察している。

1966 年 6 月, 九州農業試験場内の圈場でイネ白葉 枯病菌を漫水接種のしたイネ苗に頂葉の萎调が高率に 発生したので，直ちに組織解剖を行なつて病原細菌の 侵入経路とその後の行動を追つた。その結果, 苗の茥 基部からの直接感染はまつたく認められず，萎调は接

* 農林省九州農業試験場 Kyushu Agricultural Experiment: Station, Chikugo, Fukuoka, Japan.
種葉の排水組織から感染2,72 した病原細菌に 起因する ことを明らかにした。なお，本報告におけるイネの葉 位の記載は植物形態学的根拠 葉を第 1 本葉とし，以後は順を追つて記載しているの で作物学的にいら本莱第 1 葉（展開第 1 葉）は第 2 本 葉になる。

本実験に際して終始御指導を賜わつた農事試験場田 上義也部長ならびに九州農業試場験病害第 1 研究室の 各位に深謝する。

\section{I. 材料および方法}

1. 供試イネ

品種：十石。播種月日：1966 年 5 月 25 日。苗代 
はビニール苗代で，まず $90 \mathrm{~cm} \times 380 \mathrm{~cm}$ の大きさで 深さ $10 \mathrm{~cm}$ に掘り起こし，围りを角材で囲って幅 $2 \mathrm{~m}$ のビニールシートを糤き耕土を $10 \mathrm{~cm}$ の深さにもど して代かきし，落办して土面が固まるのを待つて播種 した。この苗代は角材の高さをかえることにより漫水 深を自由に調節することができる。なお，耕種基準おう よび管理は一般苗代に準じた。

\section{2. 病原細菌の揬種}

1966 年 6 月 9 日の夕刻, 播種後 15 日のイネ苗(3.1 菜期) に浸水接種した。供試菌は Q-6612 菌（病原性 型II，溶菌型A）で使用直前に分離した 48 時間培盖 のものを用いた。イネ苗が完全に水没するように苗代 に水を入れ， $1 \times 10^{9} / \mathrm{ml}$ 程度の病原細菌浮遊液約 200 $\mathrm{m} l$ を灌水中に滴下して軽く攢汼し，灌溉水中の菌夜 濃度を $6 \times 10^{5} / \mathrm{m} l$ になるよらにした。約 16 時間後 （翌朝）に落水して接種を完了したが，接種中は上部 をよしずで狼つた。

\section{3. 試料の作製}

1966 年 6 年 24 日汇萎调株 (6.2 葉期) を採集し, 直ちにフォルマリン・醌酸・酒精混 合液 (No. 2) で 固定して，常法にしたがつて脱水，パラフィン埋藏, 厚さ $20 \mu$ の連続切片とした。

4. 染 色

染色は石炭酸チオンンとオレンジGにより染分ける Stoughton 氏の細菌および菌類染色法》を用いた。

\section{II. 結 果}

\section{1. 萎调症状株の発生}

発病は接種 5 日後からはじまり，第 2 ，第 3 ，第 4 本葉に黄色の普通型病斑を形成した，萎调症状はそれ から 10 日後，接種日から数えて 25 日後に発生した が，第 5 本葉 (接種時末抽出葉) は外観はまつたく健 全のまま第 6 本葉 (接種時未抽出葉) が一斉に萎调す るといら 1 葉とびの現象が現われた (Fig. III)。

\section{2. 各葉の導管連絡}

萎调症状株の茎基部の連続切片（Fig. III）につい て，第2〜第7本葉の大維管束 7 本をたどつて導管の相 互連絡を調べ，偶数位葉を中心に展開したのが第 1 図 である。図で明らかなように偶数位葉と奇数位葉の大 維管束は互に合流することなく，独立しているので各 葉位の導管連絡は葉序にしたがえば当然 1 葉とびにな る。今回発生した荌调症状が第 5 本葉をとばして第 6 本葉に現われたことは，導管連絡からみてもまた稻白 葉枯病が導管病であることからしても当然と考兄る。

\section{3. 病原細菌の行動}

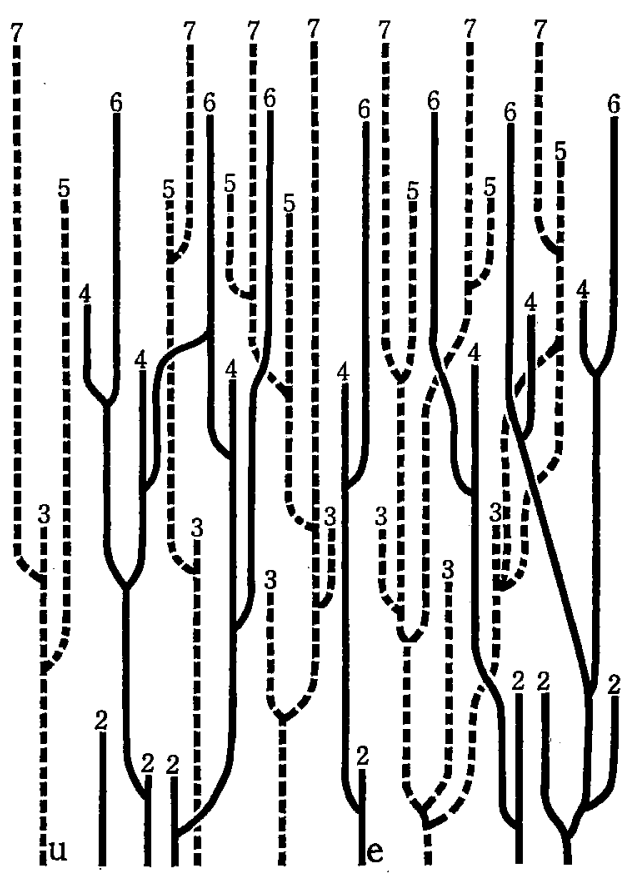

Fig. 1. Connection of the vessels of the rice seedling.

e : midrib of the even-numbered leaves.

$\mathbf{u}:$ midrib of the uneven-numbered leaves.

病原細菌は第 2 , 第 3 , 第 4 本葉の維管束部江存在 し，外観健全である第 5 本葉および萎调した第 6 本葉 の維管束にまで扰よんでいる (Fig. II-1)。第 2，第 3 ，第 4 本葉は接種葉であり（ただし第 4 本葉は接種 当時は 0.1 葉), しか子黄色の普通型病斑を葉身に形 成しているので，これらの葉の葉䩗基部の維管束中の 病原細菌恃全て葉身の排水組織から感染したものであ る。第 5 本葉㧍よび第 6 本葉は接種時には未抽出であ $\eta$ ，特に第 5 本葉は萎调症状が発現した時期において も外観煡全なので，この阿葉の葉鞘基部維管束中の病 原細菌は自らの葉身の排水組織からの感染ではなく $\tau$ ，第 5 本葉維管束中の病原細菌恃第 3 本葉維管束加 5 , 同様汇第 6 本菜維管束中の病原細菌は第 4 本葉維 管束から增殖移行したものと考えた。病原細菌の根か らの感染，および根が葉鞘基部を貫通して伸長した際 に生じた傷口から侵入して維管束を侵すといつた茎基 部からの直接感染はまつたく認められなかつた（Fig. III-16 20)。

茎基部維管束に扣ける病原細菌の充満は第 4 本葉が もつともいちじるしい（Fig. II-5〜7)。今回の萎调 
Plate I
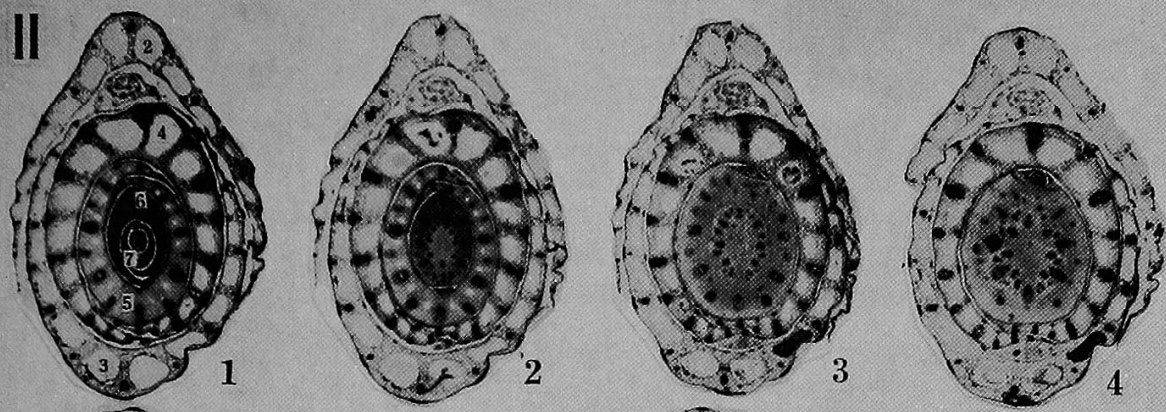

s.:-

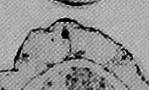

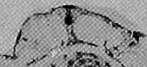

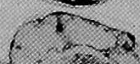

$t^{3} x^{3}=2,19$
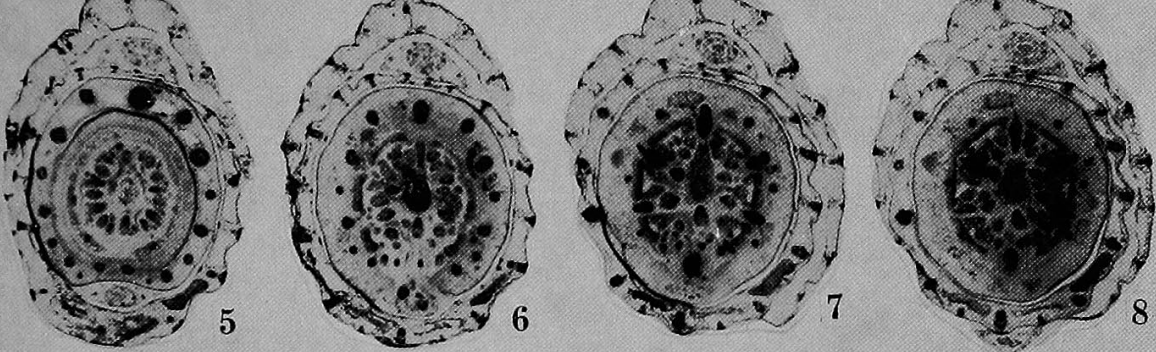

s.

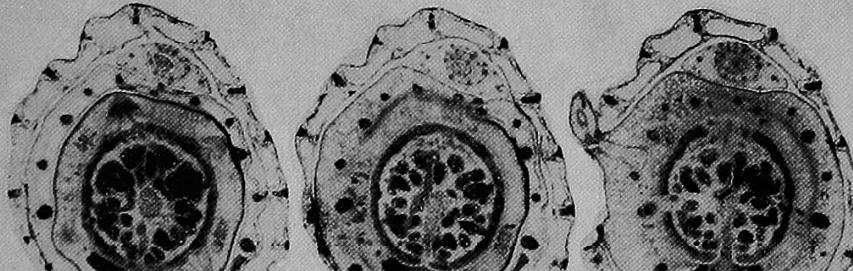

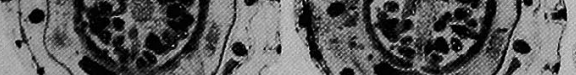
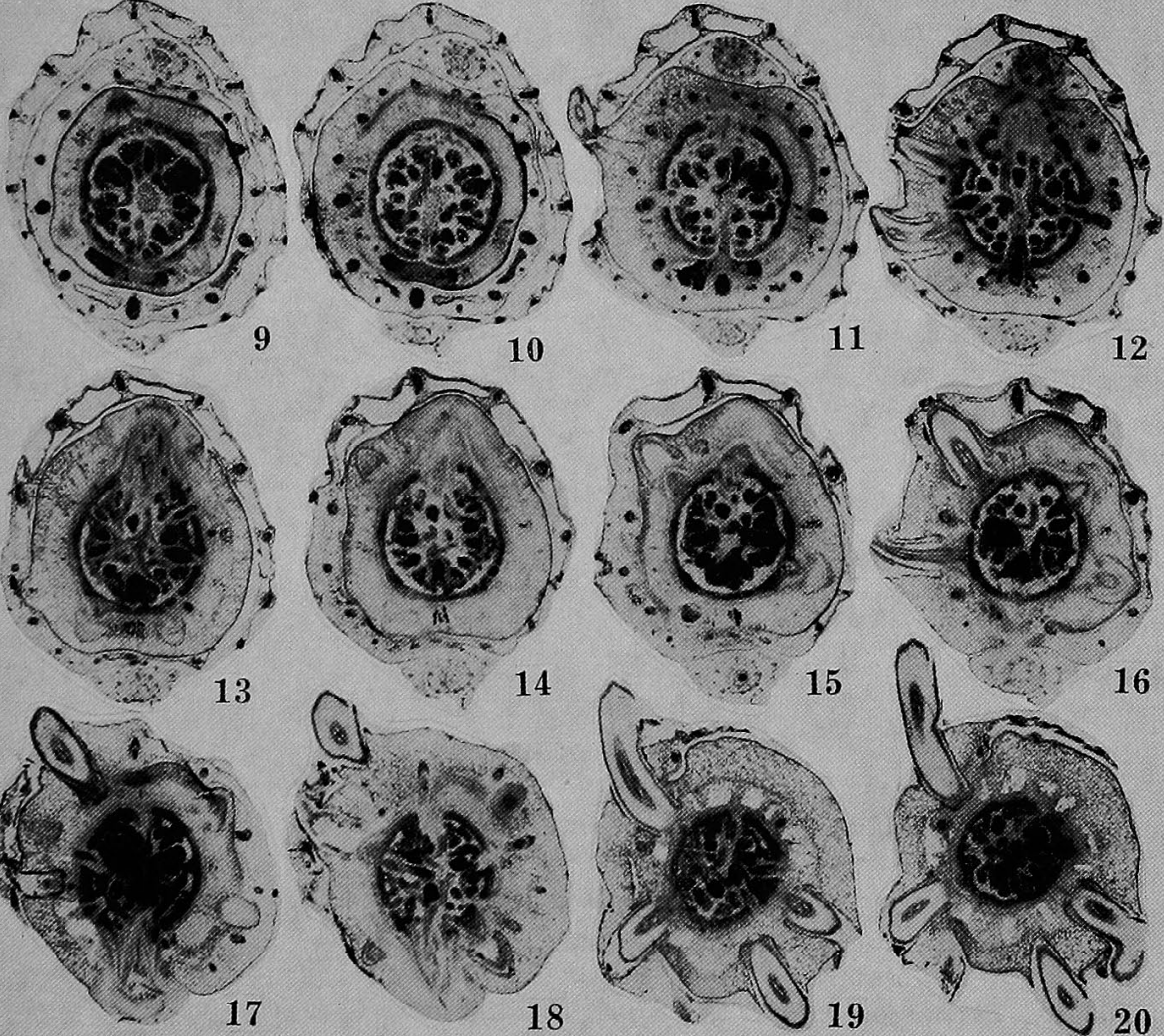


\section{Plate II}

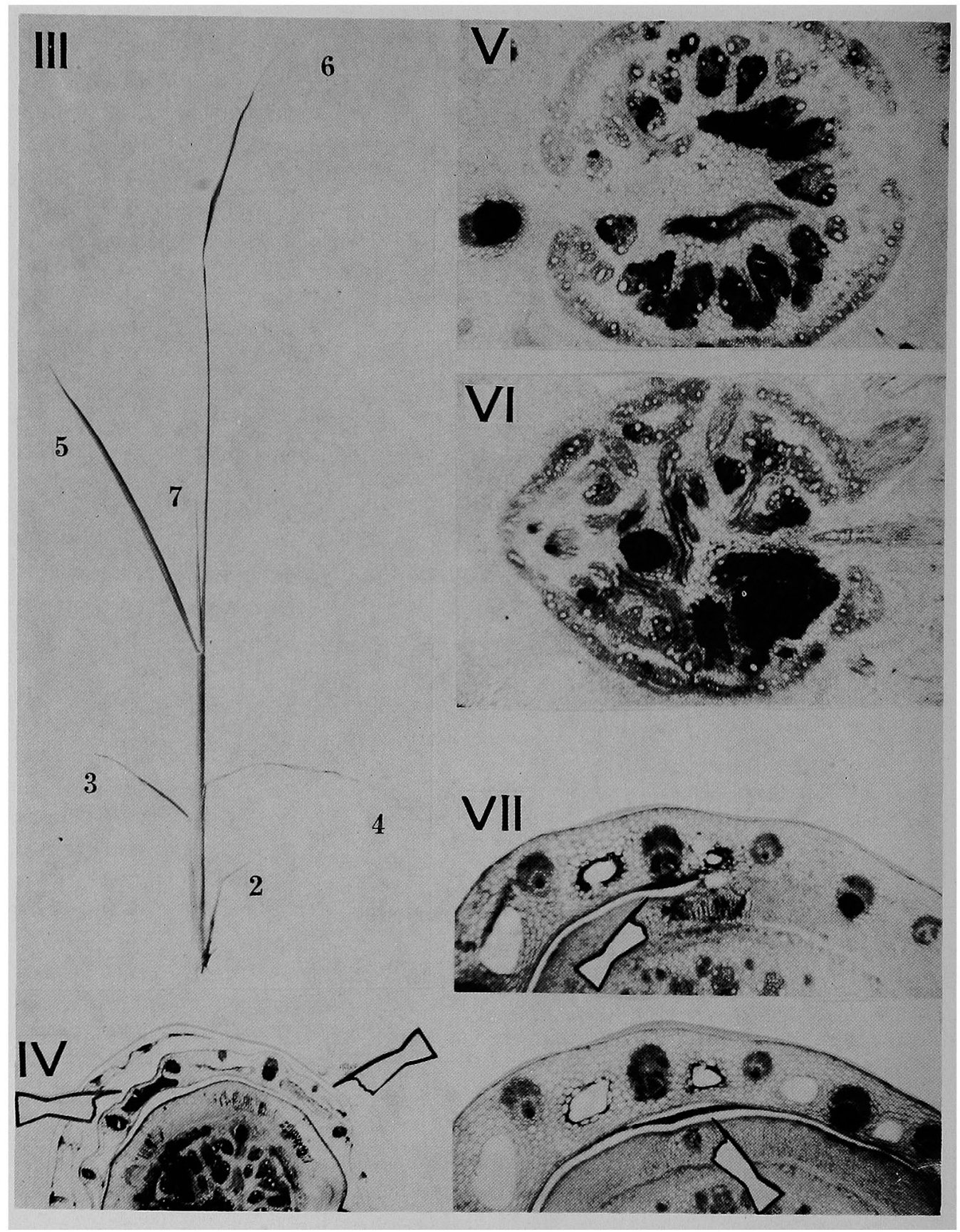

Explanation of plates

Fig. II. Cross section of the wilted seedling. $(\times 20)$

Fig. III. Wilted seedling.

Fig. IV. Bacteria exuded into the lacuna of leaf sheath. $(\times 40)$

Fig. $\nabla$, V. Bacteria exuded into the intercellular space of parenchyma. $(\times 60)$

Fig. VII. Bacterial exudation at the inside of leaf sheath. $(\times 60)$ 
症状は第 6 本葉に現われたがこれは第 4 本葉におけ る病原細菌の增殖がとくに良好で供給量も多かつたた めに,これと直接連絡している第 6 本葉の導管閉そく が特に顕著に現われた結果と解釈した。このように萎 调病状の発現は単に萎调に叔ける病原細菌の增殖の及 ではなく，同側の下葉における病原細菌の生産能力つ まり供給量が大きく関係するのではなかららか。

維管束部に扎ける病原細菌の增殖が進むと，導管は 内側から裂けて病原細菌は維管束䩗の外に流出し，柔 組織の細胞間陵中にひろがり，葉䩗部では細胞間空腔 部をみたしたり（Fig. IV)，菱基部では 2 つの導管か ら流出した病原細菌塊が合流したり（Fig. V，VI）, ついには外部に達して葉䩗内側に充満する場合も認め られた（Fig. VII)。しかしこの場合維管束の破裂は内 側からおこるものであつて，反対に柔組織の細胞間隙 中に流れ出た病原細菌が直接健全維管束を侵すことは ない。

\section{III. 論 議}

イネ白葉枯病による急性萎调病について，吉村 ${ }^{10}$ は

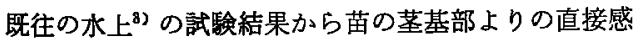
染を推定している。すなわち，病原細菌は根原基が伸 長するためにできた茎基部皮層組織の破損部から柔組 織内に侵入して，さらに增殖して組織の崩壤を扣こす と共に根の中心柱に入り，これにつながる噵走維管束 に移行して他の部位に移動增殖を重ねる結果茎基部下 部の維管束が閉そくし，そのために株の急激な萎调が おこるのではないかとした。

今回発生した萎调定状の組職観察の結果はこれと異 なり, 病原細菌の茎基部からの直接感染は認められ ず，感染は莱身の排水組織からで，導管内に侵入した 病原細菌は葉鞘内を下降して樭基部に至り，茎基部の 導管を閉そくする結果，若い上葉が萎调することを明 らかにできたなな摸调症状の場合は病原細菌の增殖 が急激なために導管は内側から裂けて柔組織の絒胞間 げき中に病原細菌の流出がおこるが，これは萎调症状 に特有の現象で,このために感染の後期になると柔組 織の細胞間隙は病原細菌が充満してやがては外部にま で達する。こうなると病原細菌の笴主体侵入から萎调 葉の出現までの一連の経過を追跡することは不可能 で，茥基部からの直接感染とみまがう恐れがあるら。

\section{IV. 摘 要}

唚水接種により出現したイネの萎调症状株の組織解 剖を行なつた結果，イネ白葉枯病の荌调症状は葉身の
排水組織から感染した病原細菌に起因することを明ら かにできた。萎调部は第 2 , 第 3 ，第 4 本葉に黄色病 斑を生じ，第 5 本葉は外钼健全のまま第 6 本葉が萎调 している。茎基部の連続切片を観察した結果，病原細 菌は接種葉である第 2 ，第 3 ，第 4 本葉の葉身排水組 織加感染して導管内に侵入乙，葉䩗内を下降して茎 基部に至り，茥基部の導管を閉そくしているが，とく に第 4 本葉に扣ける病原細菌の增殖が顕著であつたた めにこれと直接逨絡している第 6 本葉が萎调したこと が判つた。茎基部に和ける各葉の導管連絡むこの葉位 の 1 葉とび現象を襄書きしている。病原細菌の根から の感染ならびに茎基部からの直接感染は認められなか つた。

病原細菌の增殖が進むと導管は内側から裂けて柔組 織の細胞間隐中に流出し, 葉鞘部では細胞間空腔部を 充満したり，蕉基部では流れ出した病原細菌塊が合流 したり，ついには外部に達することがある。この現象 は萎调症状株に特有のものであるが，ただし導管の破 裂はあくまて内側からおこつており，反対に柔組織の 細胞間隙中の病原細菌による健全雓管束の侵害は認め られなかつた。

\section{引用文 献}

1. 岩田和夫 - 吉村彰治 (1965). 日植病報, 30 (2): 72 (謴要).

2. 水上武幸 (1956). 佐賀大学農学樗報第 4 号：169 -175 .

3. 水上武幸 (1961). 同上第 13 号 : 1-85.

4. 中山治彦 (1960). 稻の形龍と機能 (松尾編). 農 業技術協会.

5. 西山市三 (1948). 細胞兾伝学研究法. 養賢堂.

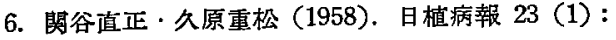
9 (講要).

7. 田部井英夫 ·向秀夫 (1960). 農業技術研究所報 告 C $11: 37-43$.

8. 田部井英夫 (1967). 日植 病報 $33(2) ： 110-111$ (講要).

9. 吉村彰治 ·岩田和夫 ·田原敬治 (1965). 北陸病 虫研会報， $13: 40-42$.

10. 吉村彰治 ·岩田和夫 · (1965). 北陸病虫研会報, $13: 42-47$. 